University of Nebraska - Lincoln

DigitalCommons@University of Nebraska - Lincoln

U.S. Environmental Protection Agency Papers

U.S. Environmental Protection Agency

1990

Site Sampling and Treatability Studies for Demonstration of WasteChem's Asphalt Encapsulation Technology Under EPA's SITE Program

Jack Hubbard

U.S. Environmental Protection Agency

Steve Tsadwa

PRC Environmental Management, Inc.

Nancy Willis

PRC Environmental Management, Inc.

Mark Evans

PRC Environmental Management, Inc.

Follow this and additional works at: https://digitalcommons.unl.edu/usepapapers

Hubbard, Jack; Tsadwa, Steve; Willis, Nancy; and Evans, Mark, "Site Sampling and Treatability Studies for Demonstration of WasteChem's Asphalt Encapsulation Technology Under EPA's SITE Program" (1990).

U.S. Environmental Protection Agency Papers. 130.

https://digitalcommons.unl.edu/usepapapers/130

This Article is brought to you for free and open access by the U.S. Environmental Protection Agency at DigitalCommons@University of Nebraska - Lincoln. It has been accepted for inclusion in U.S. Environmental Protection Agency Papers by an authorized administrator of DigitalCommons@University of Nebraska - Lincoln. 


\title{
Site Sampling and Treatability Studies for Demonstration of WasteChem's Asphalt Encapsulation Technology Under EPA's SITE Program
}

\author{
Jack Hubbard \\ U.S. EPA Office of Research and Development \\ Cincinnati, Ohio \\ Steve Tsadwa, Nancy Willis and Mark Evans \\ PRC Environmental Management, Inc. \\ McLean, Virginia
}

The U.S. Environmental Protection Agency (EPA) is conducting demonstrations of a number of innovative cleanup technologies at Superfund sites across the nation. Conducted under the Superfund Innovative Technology Evaluation (SITE) program, the purpose of these technology demonstrations is to evaluate the capabilities and costs of innovative technologies under actual field conditions. These technology demonstrations involve considerable planning and costs, both to EPA and to the technology developers. Therefore, it is important to select sites with adequate quantities of wastes at high enough concentrations to allow clear comparisons between the treated and untreated wastes. It is also important to conduct treatability studies before final selection of a site to determine if the technology to be demonstrated is effective in treating the wastes that are present and allow the technology developer to establish operating parameters for the demonstration. This paper presents a sampling approach that was used to determine whether there were adequate quantities and concentrations of wastes at the Woodland Township Route 532 Site for demonstration of an asphalt encapsulation technology developed by WasteChem Corporation. This paper also presents the result of a bench-scale treatability study conducted by the WasteChem Corporation on wastes from this site. The WasteChem Corporation later withdrew its plan to demonstrate its technology based on cost disadvantages in comparison to other cleanup technologies that involve solidification.

The preliminary sampling and analysis confirmed most of the types of organic and inorganic contaminants found at the Woodland Township Route 532 site during the remedial investigation (RI). However, the contamination levels varied over relatively short distances across the site for some contaminants.

The bench-scale treatability study indicated that, when compared with concentrations in the untreated waste, WasteChem's asphalt encapsulation technology reduced semivolatile organic compound (SVOC) concentrations in the toxicity characteristic leaching procedure (TCLP) extracts of treated wastes. The study also indicated that metals concentrations in the TCLP extracts were lower in the treated

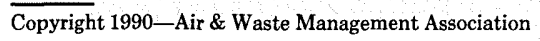

wastes than the untreated wastes in some samples and higher in others. Further studies would be required to explain these variations in leachable metals.

\section{Process Description}

The WasteChem technology dries and grinds wastes into fine particles as they are encapsulated in a hot (approximately $300^{\circ} \mathrm{F}$ ) liquid asphalt binder, which then solidifies at ambient temperatures. A major advantage of the WasteChem technology is that it reduces the volume of the wastes and thus reduces the cost of handling and disposing of the treated material. The amount of reduction achieved is a function of the water content of the waste. ${ }^{1}$

The waste stream is heated to allow evaporation of water and volatile organic compounds that may be present. Simultaneously, the solid material is reduced in size and coated and homogenized with liquid asphalt. Water vapor and a portion of any VOCs are condensed and treated through a carbon adsorption unit. Residual organic contaminants in the gaseous stream are removed through another carbon adsorber/filter to control releases to the atmosphere. Figure 1 shows a schematic of the treatment process.

The major component of the WasteChem process is the twin-screw extruder/evaporator, a widely used technology for products that require mixing of various ingredients in specified sequences at desired temperatures. This component is included in a process module 8 feet wide by 30 feet long by 9 feet high. In addition, the WasteChem equipment consists of an asphalt supply module, a waste-feed module, and a pollution-control module. All four modules can be mounted on transport trailers.

WasteChem reports that this technology has been successfully applied to more than 50 types of wastes, including sludges contaminated with metals, polychlorinated biphenyls (PCB), phenols, dioxin, and polynuclear aromatic compounds; incinerator scrubber wastes and ashes; paint and electroplating sludges; and residues from coal liquefaction, gasification, and coking.

The WasteChem process was developed initially for use in nuclear waste solidification. Its applicability for hazardous waste is limited in several ways according to WasteChem. 


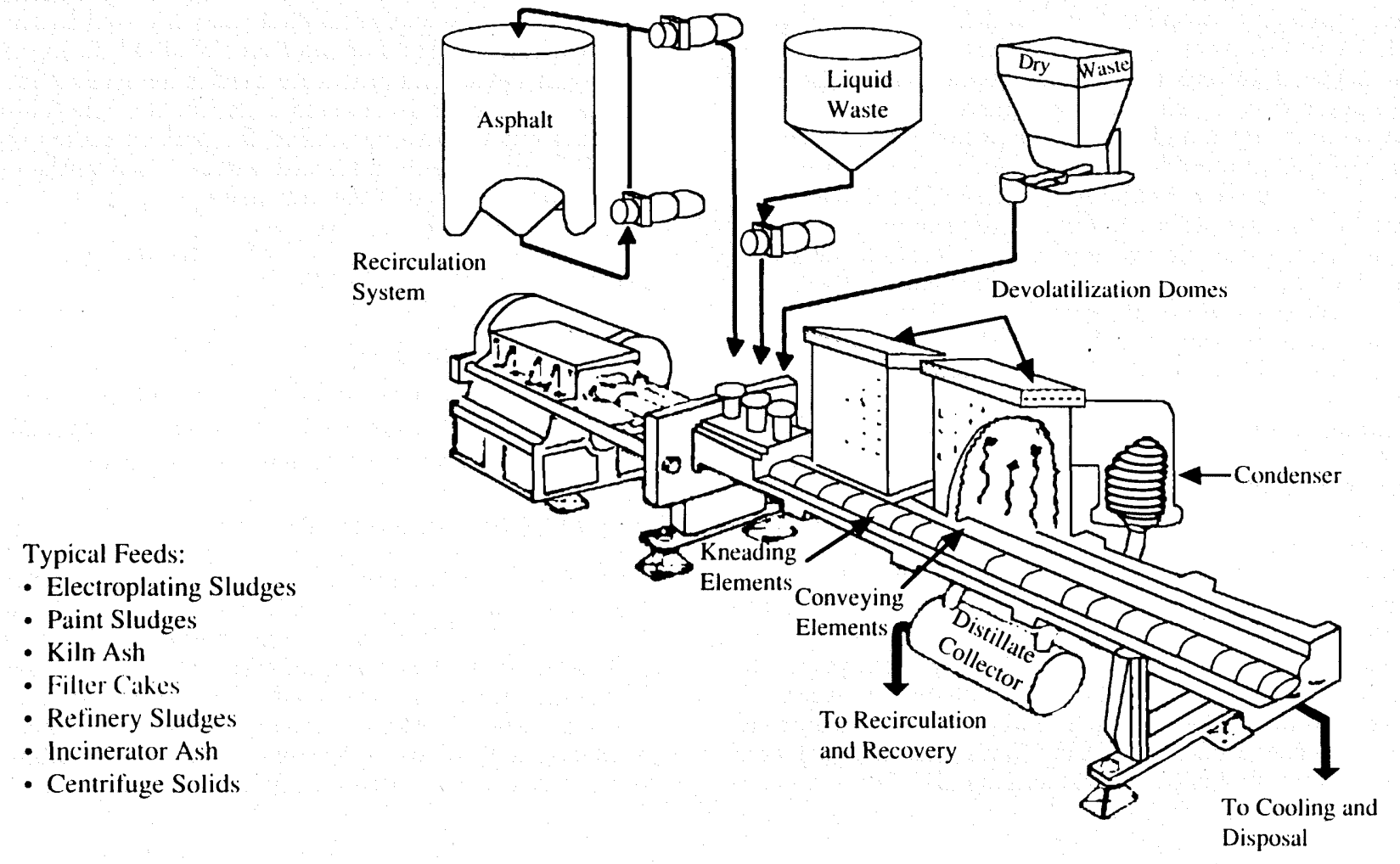

Note: From WasteChem Corporation, 1987, Proposal for

Demonstration/Development of Innovative Technologies for Halardous

Waste Site Cleanup.

Figure 1. Volume reduction and solidification system schematic.

First, it cannot process wastes that contain greater than 10 percent SVOCs. Second, it cannot process nonfriable solids greater than $1 / 4$-in. in diameter. In addition, WasteChem has determined that the process is not cost competitive with other solidification technologies for soils.

\section{Site Description}

The Woodland Township Route 532 site is in Burlington County, New Jersey. It covers approximately 20 acres within the Pinelands National Reserve. Between 1956 and 1962, the site owner accepted approximately 40 tons of chemicals, 4,000 tons of organic wastes, 4,000 tons of solids contaminated with organic liquids, 200 tons of wastes contaminated with heavy metals, and 50,000 tons of dry scrap material. These wastes are now distributed over a large area of the site and the waste, debris, and soils have intermingled, resulting in a complex distribution of contamination at the site. ${ }^{2}$

The site was tentatively selected for the demonstration of the WasteChem technology because the types and concentrations of contaminants reported in the RI conducted for the New Jersey Department of Environmental Protection (NJDEP) appeared to be consistent with the wastes previously treated successfully with the WasteChem technology. In addition, the site is accessible from Route 532, although only one 40-ft. trailer can enter and turn around at a time via the access road. In addition, power lines exist within $1 / 4$-mile of the site, but no water or sewer service is available. ${ }^{3,4}$
Using data reported in the RI, EPA selected four soil sampling locations for the preliminary sampling effort that would likely yield samples with different types and concentrations of hazardous constituents. These four sampling locations (identified throughout this summary as Locations A, B, C, and D) contained soils contaminated with different levels of VOCs, SVOCs, pesticides, and metals, as well as a tarry material found at the site.

\section{Procedures for Sampling, Analysis, and Treatablity Studles}

Sampling equipment included a hand auger, dedicated scoops, glass sampling jars, and polyethylene buckets. All sampling and analysis procedures and equipment used in this study are consistent with protocols under the EPA contract laboratory program.

At each sampling location, EPA contractors collected samples for characterization of the raw wastes and for a treatability study to be conducted by WasteChem. At two of the four sampling locations (A and B), the samples were taken at the surface. These samples included soil and tarry material. Extraneous material, such as large rocks and debris, was separated from the samples. At the other two locations, samples were taken from $1.5 \mathrm{ft}$. below the surface (Location $\mathrm{C}$ ) and $7 \mathrm{ft}$. below the surface (Location $\mathrm{D}$ ).

For waste characterization, five waste samples were collected at Locations A, B, and C. Only three waste samples were taken at Location $D$ because of an equipment problem. The waste samples from Locations A, B, and C were taken 


\section{CONTROL TECHNOLOGY}

from a primary sampling point and four other sampling stations 10 feet away from the primary point to the north, east, south, and west, respectively. At Location D, samples were taken from a primary point and at two supplemental points ten $\mathrm{ft}$. north and west of the primary point. Figure 2 provides a diagram of how samples were taken at each location. The purpose of taking multiple samples at each sampling location was to allow EPA to determine if sufficient contaminated material existed at each location for a fullscale demonstration of the treatment technology. Each sample was mixed thoroughly with a sampling trowel before being placed in sample containers. Each sample was analyzed for total concentrations of VOCs, SVOCs, pesticides, and metals. ${ }^{3}$

Samples for the bench-scale treatability study (conducted by WasteChem) consisted of a 1-gal. bucket of the soil collected at the primary point at each sampling location. Each sample was divided into three subsamples; one subsample was left untreated; one subsample was mixed with asphalt in a ratio of 50:50 (asphalt to waste, by weight); and one subsample was mixed with asphalt in a ratio of 70:30 (asphalt to waste, by weight).

After the treatment process was applied to the waste, the concentrations of leachable hazardous waste constituents in the treated wastes were compared with those in the untreated wastes based on the TCLP. The TCLP extracts were analyzed for SVOCs, pesticides, and metals.
It is important to note that treatment by asphalt encapsulation does not necesarily reduce total concentrations of contaminants, but reduces their leachability. ${ }^{3}$ Therefore, in comparing the leachable constituents of untreated and treated waste, the analytical data were adjusted to account for the dilution effects of the asphalt added during treatment. The detection limits were used to determine the percent reductions for undetected constituents. The following equation was used to determine the percent reductions in leachable constituents in treated wastes, based on the initial concentrations found in the raw waste.

where:

$$
R=\left(1-\frac{T C L P_{t w}}{T C L P_{r w} \times F_{r w}}\right) \times 100
$$

$R=$ percent reduction

$T C L P_{t w}=$ concentration of TCLP extract of treated waste

$T C L P_{r w}=$ concentration of TCLP extract of raw waste

$F_{r w}=$ fraction of raw waste in treated waste

\section{Results of Site Sampling and Analysis}

The results of the preliminary sampling effort indicate that the contamination at the Woodland Township Route 532 site varies widely across relatively short distances for some pollutants. This variation was particularly evident in the results of lead and zinc analyses at Locations $A$ and $B$ (Figures 3 and 4). At Location A, lead concentrations increased from 21 to $890 \mathrm{mg} / \mathrm{kg}$ from east to west (a distance of $20 \mathrm{ft}$.), but zinc concentrations decreased from 9,200 to 340
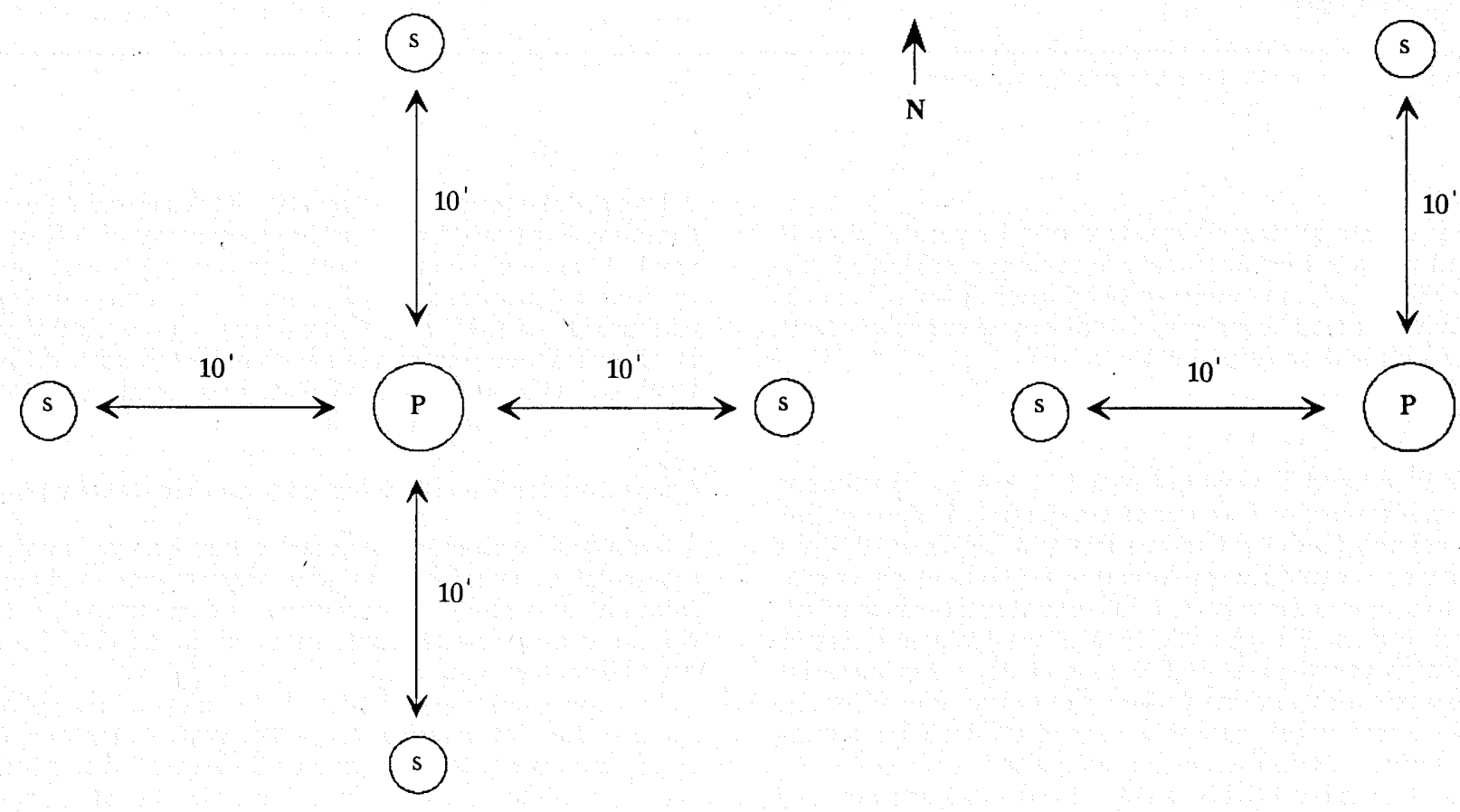

Locations A, B, and C

Location D

Figure 2. Positioning of primary and supplemental sampling points at sampling Locations $A, B, C$ and D. 


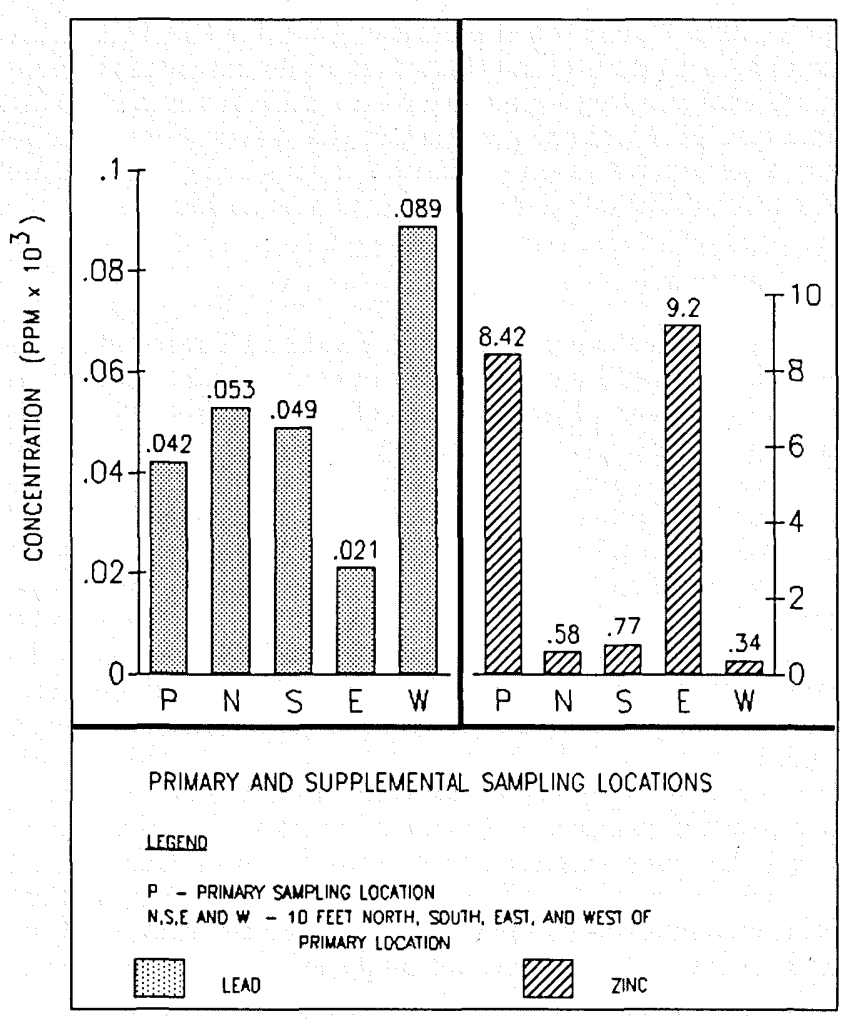

Figure 3. Variability of lead and zinc concentrations at Location A.

$\mathrm{mg} / \mathrm{kg}$. At Location B, lead and zinc concentrations are highest in the north. Zinc concentrations at Location $B$ decreased by almost $200,000 \mathrm{mg} / \mathrm{kg}$ in a distance of only $10 \mathrm{ft}$.

There was less variability at Location $C$ than at Locations $\mathrm{A}$ and $\mathrm{B}$. Lead concentrations were below detection limits $(4.5 \mathrm{mg} / \mathrm{kg})$ in the four supplemental samples from Location C. The primary sample had a concentration of $5.03 \mathrm{mg} / \mathrm{kg}$. Zinc was detected at $16.8 \mathrm{mg} / \mathrm{kg}$ in the primary sample and at $6.9 \mathrm{mg} / \mathrm{kg}, 10.2 \mathrm{mg} / \mathrm{kg}, 3.5 \mathrm{mg} / \mathrm{kg}$, and $4.5 \mathrm{mg} / \mathrm{kg}$ in the supplemental samples.

At Location D only two supplemental waste samples (north, west) were taken and analyzed during the preliminary sampling effort. There were some variations within the

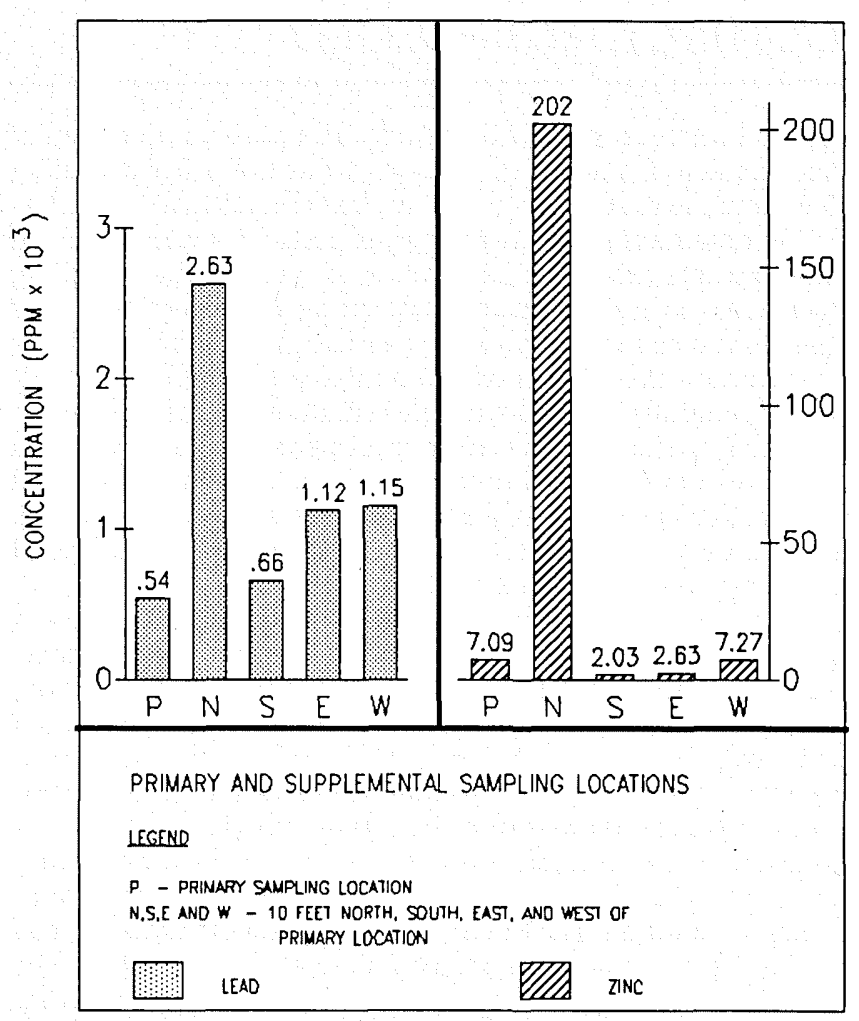

Figure 4. Variability of lead and zinc concentrations at Location B.

lead and zinc concentrations, but not as high as those observed in Locations A and B. Lead was detected at $14 \mathrm{mg} / \mathrm{kg}$ in the primary sample and was below detection limits (4.5 $\mathrm{mg} / \mathrm{kg}$ ) in the two supplemental samples. Zinc was detected at $146 \mathrm{mg} / \mathrm{kg}$ in the primary sample and at 85.4 and $14.5 \mathrm{mg} /$ $\mathrm{kg}$ in the supplemental samples.

\section{Results of the Treatabillty Study}

The results of the bench-scale treatability studies indicated that SVOC concentrations in TCLP extracts from the treated waste were lower than those in the extracts from untreated waste. Table I summarizes these results for the

Table I. Concentrations of semivolatile organic compounds in TCLP extracts of raw and treated waste from Location A.

\begin{tabular}{|c|c|c|c|c|c|}
\hline Compound & $\begin{array}{c}\text { Raw waste } \\
\text { average }(\mu \mathrm{g} / \mathrm{L})^{\mathrm{a}}\end{array}$ & $\begin{array}{c}\text { Treated waste } \\
(30 \% \text { waste to } \\
\text { asphalt mixture }) \\
\text { average }(\mu \mathrm{g} / \mathrm{L})^{\mathrm{b}}\end{array}$ & $\begin{array}{l}\text { Percent } \\
\text { reduction } \\
\text { of leachable } \\
\text { constituent }^{c}\end{array}$ & $\begin{array}{l}\text { Treated waste } \\
(50 \% \text { waste to } \\
\text { asphalt mixture) } \\
\text { average }(\mu \mathrm{g} / \mathrm{L})\end{array}$ & $\begin{array}{c}\text { Percent } \\
\text { reduction } \\
\text { of leachable } \\
\text { constituent }^{c}\end{array}$ \\
\hline Phenol & 3,050 & 111 & 89 & 92 & 94 \\
\hline Benzyl alcohol & 1,700 & 153 & 70 & 220 & 74 \\
\hline 2-Methylphenol & 875 & ND & 81 & ND & 89 \\
\hline 4-Methylphenol & $610^{\mathrm{d}}$ & $\mathrm{ND}$ & 73 & ND & 84 \\
\hline Benzoic acid & $21,000^{\mathrm{e}}$ & ND & 96 & 863 & 98 \\
\hline $\begin{array}{l}\text { 4-Chloro-3- } \\
\text { methylphenol }\end{array}$ & $580^{\mathrm{d}}$ & ND & 71 & $\mathrm{ND}$ & 83 \\
\hline Di-n-butyl phthalate & 620 & ND & 73 & $\mathrm{ND}$ & 84 \\
\hline $\begin{array}{l}\text { Bis(2-ethylhexyl) } \\
\text { phthalate }\end{array}$ & $11,650^{\mathrm{e}}$ & $\mathrm{ND}$ & 99 & ND & 99 \\
\hline Di-n-octyl phthalate & 630 & ND & 74 & ND & 68 \\
\hline
\end{tabular}

$\mathrm{ND}=$ not detected.

a From duplicate analyses.

b From triplicate analyses.

c Percent reduction was calculated using the formula given in the Procedures Section.

d Mass spectrum does not meet criteria for confirmation but indicates compound presence.

e Target analyte exceeded the linear range of the standard calibration curve. 


\section{CONTROL TECHNOLOGY}

treated waste from Location A. SVOCs were not detected in the extracts from the raw wastes from the other sampling locations, so reductions could not be demonstrated. Similarly, no detectable concentrations of pesticides were found in the extracts from the raw waste at any of the sampling locations, so no conclusions regarding the effectiveness of the technology with respect to pesticides could be drawn. As mentioned, the results of the analyses for metal contaminants generally showed variable reductions in metal concentrations in the extracts after treatment. Table II displays these results for all sampling locations. The quality control results for these semivolatile analyses showed that check standards were within ten percent, blanks were clean, and all spike recoveries were within ten percent.

Table II shows a number of instances where the treatment process appears to have caused increases in leachable metals. There are several possible reasons for this observation. First, the constituent concentrations in different portions of the raw waste may vary greatly. Therefore, the portion of raw waste that was treated may have had lower concentrations of contaminants than the treated portion. Second, the extraction and analytical process may introduce variability in the results. Third, the asphalt process may introduce some contaminants. Finally, the treatment process may make the contaminants present more easily extracted. The quality control results for these metals analyses showed that all check standard recoveries were within ten percent, blanks were clean, and all spike recoveries were within 25 percent.

It should be noted that greater reductions of leachable constituents may have occurred with a different leaching procedure. Under the standard method for the TCLP, the sample is ground to less than $1 \mathrm{~cm}$ in its narrowest dimension. This grinding step may have a significant impact on the test results of technologies such as the WasteChem technology that depend on encapsulation or solidification to reduce the leachability of contaminants from hazardous wastes. ${ }^{3}$

\section{Conclusions}

The results of sampling at the Woodland Township Route 532 site showed high variability in contaminant concentrations within sampling distances of 10 to 20 feet. This variability illustrates the importance of collecting a number of samples in each prospective waste source area during preliminary sampling at sites that are candidates for SITE demonstrations. For example, if only one sample (instead of five) were taken from Location $B$, the analysis would have indicated a zinc concentration of anywhere between 2,030 and $202,000 \mathrm{mg} / \mathrm{kg}$. If the one sample had a low zinc concentration, this area may have been rejected for use during a SITE demonstration. Compositing is one method of taking a number of samples from each waste source area while avoiding the cost of multiple analyses in each area. However, compositing samples does not allow the identification of concentration gradients within a sampling area. One method of identifying gradients while avoiding excessive analytical costs is to take one composite sample for a complete analysis and several other samples for analysis of key contaminants only.

The WasteChem process reduced the concentrations of leachable SVOCs in wastes from one location at the Woodland Township Route 532 site. However, leachable metal concentrations in the treated wastes were sometimes higher and sometimes lower than those in the raw wastes. Since a

Table II. Concentrations of metals in TCLP extracts from raw and treated wastes from all locations.

\begin{tabular}{|c|c|c|c|c|c|}
\hline & $\begin{array}{c}\text { Raw waste } \\
\text { average }(\mu \mathrm{g} / \mathrm{L})^{\text {a }}\end{array}$ & $\begin{array}{c}\text { Treated waste } \\
(30 \% \text { waste to } \\
\text { asphalt mixture) } \\
\text { average }(\mu \mathrm{g} / \mathrm{L})^{\mathrm{a}}\end{array}$ & $\begin{array}{c}\text { Percent } \\
\text { reduction } \\
\text { of leachable } \\
\text { constituent }^{\mathrm{b}}\end{array}$ & $\begin{array}{c}\text { Treated waste } \\
(50 \% \text { waste to } \\
\text { asphalt mixture) } \\
\text { average }(\mu \mathrm{g} / \mathrm{L})^{\mathrm{a}}\end{array}$ & $\begin{array}{c}\text { Percent } \\
\text { reduction } \\
\text { of leachable } \\
\text { constituent }^{b}\end{array}$ \\
\hline \multicolumn{6}{|l|}{ Location A } \\
\hline Cadmium & ND & 5 & -317 & ND & UD \\
\hline Chromium & 9.1 & 10.6 & -288 & 11.9 & -162 \\
\hline Copper & 15.3 & 5.1 & -11 & 7.5 & 2 \\
\hline Lead & 18.7 & ND & -221 & ND & -93 \\
\hline Nickel & 21.3 & 25.3 & -296 & ND & -88 \\
\hline Zinc & $8,853.0$ & 5,427 & -104 & 7,488 & -69 \\
\hline \multicolumn{6}{|l|}{ Location B } \\
\hline Cadmium & 12 & ND & -11 & 10.9 & -82 \\
\hline Chromium & 22.3 & 12.3 & -84 & 14.3 & -28 \\
\hline Copper & 222.3 & 20.7 & 69 & 28.3 & 75 \\
\hline Lead & 27 & ND & -122 & 27 & -100 \\
\hline Nickel & 68.7 & 20 & 3 & ND & 42 \\
\hline Zinc & 34,900 & 1,744 & 83 & 2,980 & 83 \\
\hline \multicolumn{6}{|l|}{ Location C } \\
\hline Cadmium & ND & 5.9 & -392 & 7.3 & -265 \\
\hline Chromium & 7.3 & 9.9 & -352 & 10.3 & -182 \\
\hline Copper & 38.3 & 10.4 & 9 & 11.7 & 39 \\
\hline Lead & 21.7 & ND & -176 & ND & -66 \\
\hline Nickel & ND & ND & UD & ND & UD \\
\hline Zinc & 338.3 & 165.7 & -63 & 210.3 & -24 \\
\hline \multicolumn{6}{|l|}{ Location D } \\
\hline Cadmium & 10.3 & 5.3 & -72 & ND & 22 \\
\hline Chromium & 18.3 & 10.6 & -93 & 10.2 & -11 \\
\hline Copper & 44.7 & 10.9 & 19 & 8.8 & 61 \\
\hline Lead & 66.7 & ND & 10 & ND & 46 \\
\hline Nickel & ND & ND & UD & ND & UD \\
\hline Zinc & 3,303 & 133.3 & 87 & 107.3 & 94 \\
\hline
\end{tabular}

$\mathrm{ND}=$ not detected; $\mathrm{UD}=$ unable to determine

${ }^{a}$ From triplicate analyses.

b Percent reduction was calculated using the formula given in the Procedures Section. 
number of possible explanations exist for the inconsistent metal results, further testing would be required to identify the true causes.

\section{References}

1. WasteChem Corporation, "Proposal for Demonstration/Development of Innovative Technologies for Hazardous Waste Site Cleanup," U.S. EPA Hazardous Waste Engineering Research Laboratory, March 1987.

2. Camp, Dresser \& McKee, Inc. "Final Draft Remedial Investigation Report for the Woodland Township Route 532 and Route 72 Hazardous Waste Sites," prepared for the New Jersey Department of Environmental Protection, December 1987.

3. PRC Environmental Management, Inc., "Results of SITE Sampling and Treatability Studies for Demonstration of WasteChem's Asphalt Encapsulation Technology Under the EPA
SITE Program," prepared for the U.S. EPA Office of Research and Development, Risk Reduction Engineering Laboratory, May 1990.

4. U.S. EPA, "Superfund Program Information Sheet. Region II Woodland Township Route 532 Site, New Jersey," August 1988.

Jack Hubbard is with the U.S. Environmental Protection Agency's Office of Research and Development, 26 West Martin Luther King Drive, Cincinnati, OH 45268. Steve Tsadwa, Nancy Willis and Mark Evans are with PRC Environmental Management, Inc., 1505 Planning Research Drive, McLean, VA 22102. This paper was submitted for peer review on July 3,1990 . The revised manuscript was received on August 24, 1990 . 